\title{
Penerapan Model Pembelajaran Kooperatif Tipe STAD untuk Meningkatkan Hasil Belajar Matematika
}

\author{
I Made Suardiana ${ }^{1 *}$ \\ ${ }^{1} 1 S D$ Negeri 2 Telaga, Singaraja, Indonesia
}

\section{ART ICLE IN F O}

Article history:

Received May 24, 2021

Revised May 27, 2021

Accepted June 25, 2021

Available online August 25, 2021

Kata Kunci:

Model Pembelajaran Kooperatif

Tipe Stad, Hasil Belajar

Keywords:

STAD Type Cooperative Learning

Model, Learning Outcome

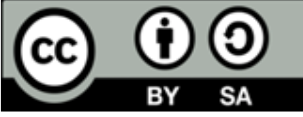

This is an open access article under the CC BY-SA license.

Copyright @ 2021 by Author. Published by Universitas Pendidikan Ganesha.

\section{A B S T R A C T}

Mathematics learning in elementary schools tends to be still not optimal, this is because the learning model used is still based on the conventional teacher-centered learning model. So the purpose of this study is to improve mathematics learning outcomes through the application of the STAD type cooperative learning model to fourth grade elementary school students. This research is classroom action research involving 12 students in grade IV. The object of this research is the result of learning mathematics. In this study, data on student learning outcomes were collected by means of a test of learning outcomes, and the method of data analysis was descriptive analysis. The results of this study indicate that mathematics learning outcomes have increased, as evidenced by the increase in learning outcomes between the first cycle (amount 820, average 68, absorption 68\%, learning completeness $75 \%$ ) and cycle II (amount 890, average 74 , absorption 74\%, learning completeness 100\%). There was an increase in learning outcomes between cycle I and cycle II, marked by an average increase in absorption of $6 \%$ and mastery learning an increase of $25 \%$. So based on the analysis of the research results, it can be concluded that the application of the STAD type cooperative learning model in fourth grade students of SD Negeri 2 Telaga in the second semester of the 2018/2019 academic year can improve mathematics learning outcomes.

\section{PENDAHULUAN}

Pembelajaran matematika merupakan salah satu mata pelajaran yang sangat penting bagi siswa, hal ini dikarenakan matematika merupakan ilmu universal yang mempunyai peran penting dalam kehidupan sehari-hari serta mampu dalam pengembangan ilmu pengetahuan lainnya (Hidayat et al., 2018; Wahyuningsih, 2019). Selain itu matematika juga merupakan bahasa simbul untuk mengekspresikan hubungan-hubungan kuantitatif dan keruangan yang memudahkan manusia berpikir dalam memecakan masalah kehidupan sehari-hari (Wulandari \& Wardani, 2017). Pembelajaran matematika dikatakan efektif apabila siswa memahami konsep dari matematika dan dapat mengaplikasikannya dalam kehidupan 
sehari-hari (Meke \& Wondo, 2020). Untuk itu, pada proses pembelajaran matematika di sekolah dasar (SD) guru tidak hanya di tuntut mampu menyampaikan materi dengan baik, tetapi juga dituntut untuk mampu memahami karaktristik siswa, sehingga tujuan pembelajaran matematika dapat tercapai.

Tujuan dari pelaksanaan pembelajaran matematika yakni untuk mengajarkan siswa mengenai cara pemecahan masalah yang meliputi kemampuan memahami masalah, merancang model matematika, menyelesaikan model dan menafsirkan solusi yang di peroleh serta memiliki tujuan untuk mengembangkan sikap menghargai dalam kehidupan sehari-hari, memiliki rasa ingin tahu, perhatian dan minat dalam pembelajaran matematika serta sikap ulet dan percaya diri dalam memecakan masalah (Istiqlal, 2017; Mulyati \& Evendi, 2020; Rahmiati et al., 2017; Surya, 2018). Untuk mencapai tujuan tersebut dalam pembelajaran matematika memerlukan metode yang variatif dan kreatif. Keberhasilan proses pembelajaran matematika dapat diukur dari tercapainya tujuan pembelajaran matematika. Keberhasilan itu dapat dilihat dari aktivitas guru yang mampu melaksanakan tugasnya dengan baik sebagai mediator, motivator, dan fasilitator siswa sehingga siswa menjadi aktif dan kreatif serta pembelajaran pun menjadi efektif dan menyenangkan.

Namun pada kenyataan di kelas dapat dilihat bahwa minat belajar siswa pada mata pelajaran matematika masih sangat rendah (Wulandari \& Wardani, 2017). Rendahnya minat belajar siswa tehadap mata pelajaran matematika bukan karena diri siswa itu saja, tetapi juga disebabkan oleh faktor cara guru di kelas. Dalam pembelajaran matematika, guru kurang tepat menggunakan metode pembelajaran, sehingga menyebabkan siswa kurang aktif dan tertarik pada mata pelajaran matematika. Selain rendahnya minat dan aktivitas belajar tersebut, terdapat berbagai macam kelemahan-kelemahan yang timbul dalam proses pembelajaran matematika, seperti pembelajaran yang masih berpusat pada guru karena metode yang digunakan masih tradisional, kurangnya antusias dan keaktifan siswa dalam proses pembelajaran, serta masih adanya tanggapan bahwa pembelajaran matematika sangatlah membosankan (Anisensia et al., 2020; Santoso, 2020; Yuniawardani \& Mawardi, 2018). Kendala-kendala yang muncul pada proses pembelajaran matematika berakibat pada rendahnya hasil belajar siswa. Hal ini didukung oleh hasil observasi yang dilakukan di SD Negeri 2 Telaga, kecamatan Busung Biu kabupaten Buleleng. Hasil observasi menunjukan bahwa pada tes awal yang dilaksanakan pada tanggal 11 Januari 2019, ratarata hasil belajar siswa sebesar $62 \%$, daya serap siswa sebesar $62 \%$ dengan ketuntasan belajar sebesar $33 \%$ (4 orang siswa tuntas). Untuk mata pelajaran matematika ditetapkan nilai KKM sebesar 70, daya serap sebesar 70\% dengan ketuntasan belajar sebesar $85 \%$. Hasil ini menunjukkan bahwa, hasil belajar matematika siswa masih tergolong rendah dan membutuhkan inovasi dalam pelaksanaan kegiatan pembelajarannya.

Salah satu upaya yang dapat dilakukan untuk menignkatkan hasil belajar matematika siswa yang dengan menerpkan model pembelajaran kooperatif tipe STAD. Pembelajaran kooperatif tipe kooperatif STAD merupakan salah satu tipe dari model pembelajaran kooperatif yang dilakukan dengan menggunakan kelompok-kelompok kecil dengan jumlah anggota tiap kelompok 4 - 5 orang siswa secara heterogen (Prananda, 2019; Puspitaningrum, 2020)(Indrawati \& Renda, 2017). Model pembelajaran STAD akan memberikan dampak dampak positif terhadap siswa yang hasil belajarnya rendah. Hal ini dikarenakan proses pembelajaran dengan menggunakan model STAD akan mengarahkan siswa yang memiliki kemampuan lebih tinggi untuk membimbing siswa yang memiliki kemampuan lebih rendah. Sehingga siswa tersebut mampu melibatkan diri dalam diskusi kelompok, baik secara sosial maupun kognitif (Subya et al., 2017; Tongato, 2017). Pada kondisi ini, siswa yang berkemampuan rendah dan berkemampuan sedang memperoleh keuntungan dalam kegiatan belajar.

Penggunaan model pembelajaran kooperatif tipe STAD akan dapat meningkatkan hasil belajar siswa melalui proses pengembangan pola interaksi interaksi dengan guru dan teman sehingga mampu merangsang pemikiran mereka yang terlibat pembelajaran sehingga kegiatan dan usaha mereka lebih produktif. Pernyataan ini sejalan dengan hasil penelitian (Kusumawardani et al., 2018) yang menunjukkan bahwa model pembelajaran kooperatif tipe STAD efektif digunakan untuk meningkatkan hasil belajar matematika siswa. Penelitian relevan lainnya yakni penelitian (Rangkuti et al., 2019) yang juga menunjukkan hasil bahwa penggunaan model pembelajaran kooperatif tipe STAD terintegrasi ICT juga dapat meningkatkan hasil belajar matematika siswa. Dan penelitian relevan yang ketiga yakni penelitian yang dilakukan oleh (Anisensia et al., 2020) mengenai penerapan model pembelajaran STAD untuk meningkatkan hasil belajar matematika SD, dimana hasil penelitiannya menunjukkan bahwa penggunaan model STAD selain dapat meningkatan hasil belajar secara signifikan juga dapat meningkatkan motivasi serta aktifitas belajar siswa.

Berdasarkan beberapa hasil penelitian tersebut dapat disimpulkan bahwa penggunaan model STAD pada pembelajaran matematika secara signifikan dapat meningkatkan aktifitas serta motivasi belajar siswa, yang secara langsung berdampak pada peningkatan hasil belajar siswa. Sehingga berdasarkan tersebut penelitian berupaya untuk melaksanakan penelitian dengan tujuan untuk 
meningkatkan hasil belajar matematika melalui penerapan model pembelajaran kooperatif tipe STAD pada siswa kelas IV SD Negeri 2 Telaga semester II tahun pelajaran 2018/2019.

\section{METODE}

Penelitian ini menggunakan jenis penelitian tindakan kelas yang berdasarkan konsep penelitian tindakan kelas dengan menggunakan siklus penelitian yang terdiri dari siklus I dan II. Model yang digunakan dalam penelitian ini adalah model spiral dari Kemmis dan Mc Taggart yang setiap siklus terdiri dari empat komponen tindakan yaitu perencanaan, pelaksanaan tindakan, observasi dan refleksi. Komponen pelaksanaan tindakan dengan observasi dalam prakteknya dijadikan sebagai satu kesatuan. Digabungkannya kedua komponen tersebut disebabkan oleh adanya kenyataan bahwa antara implementasi pelaksanaan tindakan dengan observasi merupakan dua kegiatan yang tidak dapat dilakukan secara sendiri-sendiri. Maksudnya, kedua kegiatan tersebut harus dilakukan dalam waktu yang sama, ketika suatu tindakan dilaksanakan maka saat itu pula pengamatan juga harus dilaksanakan.

Siklus I dimulai dengan perencanaan pembelajaran yang dilakukan dengan menyusun menyusun RPP, menyusun instrumen yang terdiri dari tes dan lembar analisis hasil belajar, menentukan materi pelajaran Matematika, serta menyiapkan media, alat peraga dan Lembar Kerja Siswa (LKS). Setelah tahap perencanaan selesain kegiatan dilanjutkan pada tahap pelaksanaan dengan melaksanakan semua perencanaan pembelajaran yang telah disusun. Tahap ketiga yakni tahap pengamatan atau obsevasi. Pada tahap ini guru mengamati setiap siswa ketika proses pembelajaran sedang berlangsung dengan menggunakan catatan guru. Pada proses pembelajaran dengan menggunakan model pembelajaran kooperatif tipe STAD, guru melakukan pengamatan dan mencatat aktivitas siswa seperti siswa yang aktif, pasif, tidak memperhatikan ataupun berbicara sendiri atau bahkan mengantuk selama proses kegiatan belajar mengajar berlangsung. Dan pada tahap terakhir yakni tahap tahap refleksi yang dilakukan dengan melihat hasil tes, pengamatan dan catatan yang telah dibuat. Jika hasilnya masih belum memenuhi batas ketuntasan belajar yang ingin dicapai, baik itu tentang hasil tes tertulis belum baik dan tuntas terhadap pembelajaran yang telah dilakukan maka dapat digunakan sebagai bahan perbaikan pada siklus II. Hal-hal yang positif pada siklus I tetap harus dipertahankan. Sedangkan kekurangan pada siklus I harus ditindak lanjuti sebagai bahan acuan perbaikan pada siklus II.

Subjek yang terlibat dalam penelitian ini yakni sebanyak 12 orang siswa kelas IV SD Negeri 2 Telaga, Kecamatan Busungbiu Kabupaten Buleleng. Penelitian ini dilaksanakan selama 4 bulan, yaitu dari bulan Januari sampai dengan bulan April 2019. Teknik pengumpulan data yang digunakan dalam penelitian ini yakni teknik tes yang berupa soal-soal pilihan ganda atau objektif yang diujikan kepada siswa untuk mengetahui hasil belajar pada mata pelajaran Matematika. Data yang dikumpulkan yaitu data hasil belajar dengan menggunakan kriteria belajar minimal (KBM) mata pelajaran Matematika di SD Negeri 2 Telaga.

\section{HASIL DAN PEMBAHASAN}

Penelitian dilakukan dengan melakukan analisis terhadap hasil setiap siklus penelitian. Adapun rekapitulasi hasil penelitian dari prasiklus, siklus I, dan siklus II dapat dilihat pada Tabel 1.

Tabel 1. Perkembangan Hasil Belajar

\begin{tabular}{lcccc}
\hline \multicolumn{1}{c}{ Uraian } & Prasiklus & Siklus I & Siklus II & Peningkatan \\
\hline Jumlah & 740 & 820 & 890 & 70 \\
Rata-rata & 62 & 68 & 74 & 6 \\
Daya serap & $62 \%$ & $68 \%$ & $74 \%$ & $6 \%$ \\
Ketuntasan belajar & $33 \%$ & $75 \%$ & $100 \%$ & $25 \%$ \\
\hline
\end{tabular}

Berdasarkan tabel 1 di atas, dapat diketahui bahwa nilai rata-rata kelas mengalami peningkatan dari 62 pada hasil belajar prasiklus menjadi 68 pada siklus I, kemudian meningkat menjadi 74 pada siklus II. Sedangkan nilai daya serap siswa juga mengalami peningkatan dari $62 \%$ pada prasiklus meningkat menjadi $68 \%$ pada siklus I, kemudian meningkat menjadi $74 \%$ pada siklus II. Ketuntasan belajar juga mengalami peningkatan dari 33\% pada hasil belajar prasiklus, naik menjadi $75 \%$ pada siklus I, kemudian meningkat menjadi $100 \%$ pada siklus II. Pada prasiklus, hasil belajar siswa dapat digambarkan bahwa rata-rata hasil belajar sebesar 62, daya serap 62\%, dan ketuntasan belajar sebesar 33\%. Hasil belajar tersebut masih jauh dari indikator keberhasilan. Adapun yang menyebabkan rendahnya hasil belajar adalah metode yang kurang tepat sehingga menimbulkan kejenuhan dalam diri siswa, siswa kurang tertarik dan aktif dalam proses pembelajaran. Selain itu, anggapan siswa yang menyatakan bahwa 
matematika adalah pembelajaran yang sulit sehingga menimbulkan sikap kurang baik seperti menyontek hasil pekerjaan temannya, siswa kurang teliti mengerjakan soal latihan dan sebagian besar siswa tidak mau ke depan kelas untuk mengerjakan latihan soal yang diberikan.

Selanjutnya pada siklus I, rata-rata hasil belajar matematika pada siklus I sebesar 68, daya serap sebesar $68 \%$ dengan ketuntasan belajar sebesar $75 \%$, hasil belajar ini sudah mengalami peningkatan namun belum memenuhi indikator keberhasilan yang ditetapkan. Adapun beberapa kendala yang berhasil diidentifikasi oleh guru terkait dengan masih belum berhasilnya penerapan model pembelajaran kooperatif tipe STAD pada siklus I yakni kondisi belajar menjadi kurang tenang, terdapat beberapa siswa asik berbicara sendiri dan bermain mainan dengan temannya, banyak siswa yang belum paham akan materi serta proses pembelajaran yang dilakukan serta. Untuk mengatasi kendala serta meningkatkan hasil belajar siswa pada siklus I, maka penelitian dilanjutkan pada siklus II.

Pada siklus II, rata-rata hasil belajar matematika pada siklus II sebesar 74, daya serap sebesar $74 \%$ dengan ketuntasan belajar sebesar $100 \%$, hasil belajar ini sudah mengalami peningkatan dan melewati memenuhi indikator keberhasilan yang ditetapkan. Adapun keberhasilan penerapan model pembelajaran kooperatif tipe STAD yang berhasil diidentifikasi oleh guru pada siklus II yakni antusiasme siswa dalam melakukan diskusi kelompok meningkat, diskusi dapat berjalan lebih efektif, serta siswa lebih serius dalam belajar karena takut mendapatkan sanksi pengurangan poin kelompok jika berbicara. Meningkatnya hasil belajar matematika dari siklus I ke siklus II, disebabkan oleh penerapan model pembelajaran kooperatif tipe STAD dengan optimal. Kegiatan pembelajaran dengan menggunakan model pembelajaran kooperatif tipe STAD dilaksanakan dengan memfokuskan pembelajaran kepada siswa (student centered) (Rambe, 2021). Pembelajaran menggunakan model pembelajaran kooperatif tipe STAD dilakukan dengan membentuk siswa kedalam kelompok belajar yang bersifat heterogen (Artini, 2016). Dalam kelompok tiap siswa kemudian diberikan perannya masing-masing sehingga dapat memaksimalkan proses belajar setiap siswa. Adapun kelebihan model pembelajaran kooperatif tipe STAD dalam pembelajaran adalah model ini membuat mereka aktif terlibat dalam pembelajaran melalui interaksi dengan guru dan teman serta akan merangsang pemikiran mereka yang terlibat pembelajaran sehingga kegiatan dan usaha mereka lebih produktif (Susanti et al., 2017). Model ini juga meningkatkan tanggung jawab siswa dalam menyelesaikan tugas yang diberikan sehingga didapat kesamaan informasi bagi semua siswa dalam kelompok tersebut (Hakim, 2018).

Hasil belajar matematika yang mengalami peningkatan melalui penerapan model pembelajaran kooperatif tipe STAD sesuai dengan hasil penelitian yang dilakukan oleh (Kusumawardani et al., 2018) yang menunjukkan bahwa model pembelajaran kooperatif tipe STAD efektif digunakan untuk meningkatkan hasil belajar matematika siswa. Penelitian relevan lainnya yakni penelitian (Rangkuti et al., 2019) yang juga menunjukkan hasil bahwa penggunaan model pembelajaran kooperatif tipe STAD terintegrasi ICT juga dapat meningkatkan hasil belajar matematika siswa. Dan penelitian relevan yang ketiga yakni penelitian yang dilakukan oleh (Anisensia et al., 2020) mengenai penerapan model pembelajaran STAD untuk meningkatkan hasil belajar matematika SD, dimana hasil penelitiannya menunjukkan bahwa penggunaan model STAD selain dapat meningkatan hasil belajar secara signifikan juga dapat meningkatkan motivasi serta aktifitas belajar siswa.

\section{SIMPULAN}

Adapun simpulan yang dari hasil dan pembahasan pada penelitian ini menunjukkan bahwa penerapan model pembelajaran kooperatif tipe STAD dapat meningkatkan hasil belajar matematika pada siswa kelas IV SD Negeri 2 Telaga semester II tahun pelajaran 2018/2019. Adapun saran-saran yang bisa dimukakan dalam penelitian ini adalah bagi guru untuk mencoba menerapkan model pembelajaran ini karena terbukti bahwa siswa merasa senang dengan proses pembelajaran. Bagi peneliti lain, untuk mempunyai motivasi untuk mengadakan penelitian tindakan kelas sebab dengan melakukan penelitian tindakan kelas, maka proses pembelajaran menjadi lebih berkualitas.

\section{DAFTAR RUJUKAN}

Anisensia, T., Bito, G. S., \& Wali, M. (2020). Penerapan Model Pembelajaran Kooperatif Tipe STAD untuk Meningkatkan Hasil Belajar Matematika pada Siswa Kelas V SDI Blidit Kabupaten Sikka. Jurnal Ilmiah Kependidikan, 1(1), 61-69. https://doi.org/https://doi.org/10.37478/jpm.v1i1.351.

Artini, N. N. M. (2016). Pembelajaran Model STAD Untuk Meningkatkan Prestasi Belajar Matematika Pada Siswa Kelas V SDN 39 Cakranegara. Jurnal Paedagogy, 3(1). https://doi.org/https://doi.org/10.33394/jp.v3i1.3033.

Hakim, A. R. (2018). Kecerdasan Interpersonal Siswa Melalui Model Student Teams Achievement 
Divisions. Elementary School Education Journal, 2(1), 51-58. https://doi.org/http://dx.doi.org/10.30651/else.v2i1.1210.

Hidayat, F., Zulhendri, \& Zulfah. (2018). Pengaruh Model Pembelajaran Kooperatif Tipe Think Pair Share (TPS) Terhadap Kemampuan Pemecahan Masalah Matematis Siswa Kelas VII SMP Negeri 1 Kuok. Journal On Education, 1(1), 30-38. https://doi.org/https://doi.org/10.31004/joe.v1i1.7.

Indrawati, N. L. G. E., \& Renda, N. T. (2017). PENERAPAN MODEL Pembelajaran Kooperatif Tipe Student Team Achievement Divisions (STAD) Untuk Meningkatkan Hasil Belajar Matematika Siswa Kelas VI SD NO . 1 Sading Kecamatan Mengwi Kabupaten Badung Semester I Tahun Pelajaran 2016 / 2017. Jurnal of Education Action and Reserch, 1(2), 68-75. https://doi.org/http://dx.doi.org/10.23887/jear.v1i2.12040.

Istiqlal, M. (2017). Pengembangan Multimedia Interaktif Dalam Pembelajaran Matematika. Jurnal Ilmiah Pendidikan Matematika, 2(1). https://doi.org/10.26877/jipmat.v2i1.1480.

Kusumawardani, N., Siswanto, J., \& Purnamasari, V. (2018). Pengaruh Model Pembelajaran Kooperatif Tipe Berbantuan Media Poster Terhadap Hasil Belajar Peserta Didik STAD. Jurnal Ilmiah Sekolah Dasar, 2(2), 170-174. https://doi.org/http://dx.doi.org/10.23887/jisd.v2i2.15487.

Meke, K. D. P., \& Wondo, M. T. S. (2020). Pengembangan Perangkat Pembelajaran Model Problem Based Learning Melalui Penggunaan Bahan Manipulatif. Jurnal Hasil Penelitian Dan Kajian Kepustakaan, 6(3), 588-600. https://doi.org/https://doi.org/10.33394/jk.v6i3.2861.

Mulyati, S., \& Evendi, H. (2020). Pembelajaran Matematika Melalui Media Game Quizizz Untuk Meningkatkan Hasil Belajar Matematika SMP 2 Bojonegara. Jurnal Pendidikan Matematika, 3(1), 64-73. https://doi.org/https://doi.org/ 10.30656/gauss.v3i1.2127.

Prananda, G. (2019). Pengaruh Model Pembelajaran Kooperatif Tipe STAD Dalam Pembelajaran Ipa Siswa Kelas V SD. Jurnal Ilmiah Pendidikan Dan Pembelajaran, 6(2). https://doi.org/https://doi.org/10.37598/pjpp.v6i2,\%20 Oktober.648.

Puspitaningrum, A. (2020). Peningkatan Hasil Belajar Siswa Melalui Penggunaan Media Kartu Bilangan Dalam Model Pembelajaran Kooperatif Tipe Stad (Student Teams Achievement Divisions) Pada Pembelajaran Pengurangan Bilangan Cacah Matematika Kelas III di SDN Cipetung. Jurnal Pendidikan Dan Profesi Pendidik, 6(2), 159-168. https://doi.org/https://doi.org/10.26877 /jp3.v6i2.7324.

Rahmiati, Musdi, E., \& Fauzi, A. (2017). Pengembangan Perangkat Pembelajaran Matematika Berbasis Discovery Learning Untuk Meningkatkan Kemampuan Pemecahan Masalah Siswa Kelas VIII SMP. Jurnal Mosharaf, 6(2), 267-272. https://doi.org/https://doi.org/10.31980/mosharafa.v6i2.314.

Rambe, A. H. (2021). Implementasi Model Students Teams Achievement Division ( STAD ) Untuk Meningkatkan Hasil Belajar dan Aktivitas Belajar Siswa. Jurnal Keislaman Dan Pendidikan, 12(1). http://e-jurnal.staiattanwir.ac.id/index.php/attanwir/index\%0AImplementasi.

Rangkuti, R. K., Ramli, M., \& Nasution, M. I. (2019). Matematika Melalui Model Pembelajaran Kooperatif Tipe-STAD Terintegrasi ICT. Jurnal Ilmiah Pendidikan Matematika, 3(1), 64-69. https://journal.iainlangsa.ac.id/index .php/qalasadi/article/view/885/618.

Santoso, K. B. (2020). Penerapan Pendekatan Kontekstual Pada Pembelajaran Matematika Untuk Meningkatkan Prestasi Siswa SMP. Jurnal Pendidikan Matematika, 8(2), 174-179. https://doi.org/10.20527/edumat.v8i1.9213.

Subya, W. O., Rahim, U., \& Suhar. (2017). Meningkatkan Hasil Belajar Matematika Siswa Kelas VII1 SMP Negeri 11 Kendari Melalui Model Pembelajaran Kooperatif Tipe STAD. Jurnal Penelitian Pendidikan Matematika, 5(1), 113-126. https://doi.org/http://dx.doi.org/10.36709 /jppm.v5i1.7314.

Surya, A. (2018). Learning Trajectory Pada Pembelajaran Matematika Sekolah Dasar (SD). Jurnal Pendidikan Ilmiah, 4(2). https://jurnal.fkip.uns.ac.id/ index.php/jpi/article/download/11692/8417.

Susanti, Y., Utaya, S., \& Wahjoedi. (2017). Peningkatan aktivitas dan hasil belajar melalui pembelajaran kooperatif tipe STAD. Jurnal Pendidikan, 2(5), 661-666. http://journal.um.ac.id/index.php/jptpp/.

Tongato. (2017). Upaya Meningkatkan Hasil Belajar Dan Aktivitas Siswa Dalam Pembelajaran Bahasa Indonesia Melalui Pembelajaran Kooperatif Tipe STAD KELAS X SMA PKP DKI Jakarta. Jurnal Manajemen Pendidikan, 2(3), 137-150. https://doi.org/https://doi.org/10.31538/ndh.v2i3.32.

Wahyuningsih, E. (2019). Pembelajaran Matematika Dengan Pendekatan Problem Based Learning Dalam Implementasi Kurikulum 2013. Jurnal Pengembangan Pembelajaran Matematika, 1(2), 69-87. https://doi.org/10. 14421/jppm.2019.012-02.

Wulandari, S., \& Wardani, K. W. (2017). Penerapan Pendekatan Scientific Dengan Menggunakan Media Konkret Untuk Meningkatkan Hasil Belajar Matematika Pada Siswa SD. Jurnal Mitra Pendidikan, 
1(5), 587-599. http://e-jurnalmitrapendidikan.com/index.php/e-jmp/article/view/113.

Yuniawardani, V., \& Mawardi. (2018). Peningkatan hasil belajar pada pembelajaran matematika dengan model problem based learning. Jurnal Riset Teknologi Dan Inovasi Pendidikan, 1(2), 24-32. https://media.neliti.com/media/publications/266970-peningkatan-hasil-belajar-padapembelaja-038080bd.pdf. 